\title{
Expression profile, clinical significance and biological functions of IGF2BP2 in esophageal squamous cell carcinoma
}

\author{
FENYING LU ${ }^{1,2}$, WEICHANG CHEN ${ }^{1}$, TINGWANG JIANG ${ }^{3}$, CUIE CHENG $^{2}$, BIN WANG ${ }^{2}$, ZHIPING LU $^{2}$, \\ GUOJIN HUANG ${ }^{2}$, JIAMING QIU ${ }^{4}$, WEI WEI ${ }^{4}$, MING YANG $^{5}$ and XIA HUANG ${ }^{2}$ \\ ${ }^{1}$ Department of Gastroenterology, The First Affiliated Hospital of Soochow University, \\ Suzhou, Jiangsu 215006; Departments of ${ }^{2}$ Gastroenterology, ${ }^{3}$ Science and Technology Division, \\ ${ }^{4}$ Pathology and ${ }^{5}$ Thoracic Surgery, The Second People's Hospital of Changshu, Suzhou, Jiangsu 215500, P.R. China
}

Received December 14, 2020; Accepted September 17, 2021

DOI: $10.3892 / \mathrm{etm} .2022 .11177$

\begin{abstract}
The ectopic expression of insulin-like growth factor 2 mRNA-binding protein 2 (IGF2BP2) has been demonstrated to facilitate tumorigenesis and induce proliferation in a various types of cancer. However, the role of IGF2BP2 in esophageal squamous cell carcinoma (ESCC) has yet been fully elucidated. In this regard, the current study assessed the expression patterns and clinical significance of IGF2BP2 in 94 Chinese patients diagnosed with ESCC. Immunohistochemistry and reverse transcription-quantitative PCR assays were employed to assess IGF2BP2 expression in ESCC tissues compared with adjacent healthy tissues. The results revealed that the protein expression of IGF2BP2 was substantially upregulated in ESCC tissues compared with adjacent ESCC tissues. More specifically, higher IGF2BP2 expression strongly associated with tumor node metastasis stage, lymphatic infiltration and lymph node metastasis. Using two ESCC cell lines (TE-1 and TE-10), the inhibition of IGF2BP2 expression by small interfering RNA was proven to induce apoptosis and suppress proliferation, migration and cell cycle progression in vitro. Collectively, the present findings indicated that IGF2BP2 may serve a major role in the development of ESCC carcinogenesis. The present study may be helpful in the design of potential drug targets in the treatment of ESCC.
\end{abstract}

\section{Introduction}

Esophageal cancer (EC) has been described as the seventh most frequently diagnosed tumor (1) and the sixth causal agent of cancer mortality with respective new cases and deaths

Correspondence to: Dr Weichang Chen, Department of Gastroenterology, The First Affiliated Hospital of Soochow University, 188 Shizi Street, Suzhou, Jiangsu 215006, P.R. China E-mail: weichangchen@126.com

Key words: downregulation, esophageal-squamous cell carcinoma, insulin-like growth factor 2 mRNA-binding protein 2, proliferation, migration estimated to be 604,000 and 544,000 in 2020, worldwide (2). An annual increase in the incidence and mortality rate of EC has been reported amidst variation with sex and region. In particular, the global incidence rate in men was reported to be three-fold higher than in women and mostly occurred in Southern Africans and Eastern Asians (3). Histologically, the existing two primary EC subtypes are esophageal adenocarcinoma (EAC) and esophageal squamous cell carcinoma (ESCC). While the former is a more common type of EC in individuals from developing nations, such as China and India, the latter is dominant among Americans (4). Treatments for ESCC vary depending on the stages of the disease: Esophagectomy, neoadjuvant therapy, chemotherapy or concurrent chemoradiotherapy (5). Although several treatment options have been developed, an improved form of treatment is required, due to the poor prognosis and low survival rates associated with a late diagnosis (6). Therefore, it is necessary to identify new potential targets of ESCC through the study of the molecular mechanisms underlying carcinogenesis for improved clinical outcome.

A previous study reported that insulin-like growth factor-2 mRNA-binding protein 2 (IGF2BP2) is a crucial oncogenic protein, functioning as a tumor promoter via post-transcriptional regulation of gene expression. IGF2BP2 is implicated in the stabilization, localization and trafficking of target mRNAs involved in carcinogenesis and cancer cell proliferation (7). Mechanistically, IGF2BP2 serves as an mRNA stabilizer for cancer development and proliferation via the IGF2BP2/microRNA (miR)-195/Raf-1 proto-oncogene, serine/threonine kinase axis in colorectal cancer cells (8), and the methyltransferase-like 3 (METTL3)/IGF2BP2/flap endonuclease 1 axis in liver cancer (9). IGF2BP2 upregulation has been reported in several types of human cancer, such as pancreatic cancer (10), glioblastoma (11), hepatic cellular carcinoma (12), acute myeloid leukemia (13) and sarcomas (14). Moreover, IGF2BP2 expression in cancer tissue was positively correlated with poor prognosis and short survival rate of patients with EAC (15). Importantly, IGF2BP2 knockdown suppressed the carcinogenesis, proliferation, invasion and metastasis of colorectal carcinoma (16). Although various evidence has reported the role and mechanisms of IGF2BP2 in several types of cancer, published reports that 
clarify the association between clinicopathological features and IGF2BP2 expression in ESCC are lacking.

In the present study, the association between IGF2BP2 expression at the protein level and the clinicopathological features of patients with ESCC was studied. The effects of IGF2BP2 knockdown on proliferation, migration and apoptosis were examined in vitro using ESCC cell lines. Based on the present research, it was hypothesized that IGF2BP2 may be a promising therapeutic target for ESCC treatment.

\section{Materials and methods}

Preparation of tissue samples and ethical statement. A total of 94 Chinese patients with ESCC (females, 28; males, 66), aged 33-78 years with an average age of 56 years old, gave their written consent to participate in the present study at the Second People's Hospital of Changshu. The inclusion criteria for participation included: i) A diagnosis of esophageal squamous carcinoma via gastroscopy and pathological examination; and ii) no evidence of serious organ dysfunction in the heart, brain, liver, lung and kidney. Patients were excluded for the current study if they: i) Could not tolerate surgery due to severe heart disease; ii) had other serious systemic diseases, such as later stage uremic syndrome; and iii) exhibited esophageal perforation or bleeding. Specimens of human ESCC tissues $(n=36)$ with adjacent tissues of ESCC $(n=36)$ and accompanying normal tissues of esophagus $(n=15)$ were collected from the same patients. Adjacent ESCC tissues were obtained $20 \mathrm{~mm}$ from the primary ESCC tumor, and normal esophagus tissues were obtained $\geq 50 \mathrm{~mm}$ from the ESCC tumor site. The three types of tissues were further identified by an experienced pathologist (JQ) based on their cell morphology and tissue characteristics. The clinicopathological tumor stage was evaluated according to the World Health Organization (WHO) and the Union for International Cancer-Control staging guidelines using tumor, nodes and metastasis (TNM) systems of classification $(17,18)$. Histological tumor grade was categorized into three groups: High, middle and low degrees of tumor differentiation, by JM Qiu based on WHO classification (17). Review and approval for the current study was provided by the Ethical committee of Changshu Second People's Hospital at Jiangsu Province (Suzhou, China).

Immunohistochemistry (IHC) analysis and pathological scoring of ESCC tissue staining. Based on a protocol of epitome retrieval (19), the tissues were fixed with $4 \%$ paraformaldehyde at room temperature $\left(25 \pm 2^{\circ} \mathrm{C}\right)$, embedded in paraffin and cut into $3 \mu \mathrm{m}$ thick sections. After deparaffinization, the slices were rinsed in water for 10 min, soaked in $\mathrm{H}_{2} \mathrm{O}_{2}$ (3\%) for $10 \mathrm{~min}$ at room temperature and washed twice further in water. The slices were then immersed in citric acid buffer (pH 6.0) for $7 \mathrm{~min}$ and boiled for $15 \mathrm{~min}$ to expose the site of antigens. After cooling to room temperature, the slices were washed twice in PBS, and 4\% skimmed milk powder was added for the blocking of non-specific binding sites in ESCC tissues at $37^{\circ} \mathrm{C}$ for $30 \mathrm{~min}$. Subsequently, sections were incubated for $1 \mathrm{~h}$ at $37^{\circ} \mathrm{C}$ with rabbit monoclonal anti-IGF2BP2 antibodies (1:200; cat. no ab124930; Abcam) mixed with milk powder (skimmed, $2 \%$ ) to minimize unspecific staining. A biotinylated secondary antibody (1:1,000; cat. no. ab6721;
Abcam) was then added for $30 \mathrm{~min}$ at $37^{\circ} \mathrm{C}$, after which IHC staining was detected using a substrate solution comprising 3,3'-diaminobenzidine and $\mathrm{H}_{2} \mathrm{O}_{2}$. Counterstaining was carried out with hematoxylin at room temperature for $30 \mathrm{sec}$. Samples were imaged using an inverted fluorescence microscope (Nikon, Ti-U; magnification, x200).

Considering the percentage of positive cells and the intensity of staining, which were determined using Image $\mathrm{J}$ software (Java 1.8.0.172; National Institutes of Health), the IHC score was divided into values as follows: 0 (negative), indicating that the whole tissue mass was $<10 \%$ stained; +1 (weakly positive), indicating that the tissue mass was $10-25 \%$ stained; +2 (moderately positive), indicating that the tissue mass exhibited $25-50 \%$ positive staining; and +3 (strongly positive), indicating that the tissue mass exhibited $>75 \%$ positive staining (20). IHC score data was presented as the median + interquartile range. IHC scores of 0 or 1 were defined as low expression, and scores of 2 or 3 were defined as high expression.

Cell lines, cell culture and transfection. Human esophageal cancer cell lines (TE-1 and TE-10) were obtained from Cloud-Clone Corp. TE-1 and TE-10 culture medium consisted of DMEM (Gibco; Thermo Fisher Scientific, Inc.) supplemented with 10\% FBS (Gibco; Thermo Fisher Scientific, Inc.), streptomycin sulfate (100 units/ml) and penicillin G (100 units/ml; Gibco; Thermo Fisher Scientific, Inc.). The cells were incubated at $37^{\circ} \mathrm{C}$ in humidified conditions and $5 \% \mathrm{CO}_{2}$.

For transfection, TE-1 and TE-10 cells were grown in six-well culture plates until confluence (70-80\%). Transfection of siRNA1 (sense, CCGUUGUCAACGUCACCUAUA; antisense, UAUAGGUGACGUUGACAACGG) and siRNA2 (sense, CCUUGCAGGAUUUGAGCAUUU; antisense, AAAUGCUCAAAUCCUGCAAGG) (Wuhan GeneCreate Biological Engineering Co., Ltd.) was performed with Lipofectamine ${ }^{\circledR} 2000$ (Invitrogen; Thermo Fisher Scientific, Inc.) at $37^{\circ} \mathrm{C}$ for $4 \mathrm{~h}$, with $20 \mathrm{nM}$ small interfering RNA negative control (siRNA-NC, sense, UUCUCCGAACGU GUCACGUTT; antisense, ACGUGACACGUUCGGAGA ATT; Wuhan GeneCreate Biological Engineering Co., Ltd.). After transfection for $48 \mathrm{~h}$, subsequent experiments were performed.

Extraction of RNA and RT-qPCR analysis. Total RNA from TE-1 and TE-10 cells, was extracted using TRIzol ${ }^{\circledR}$ reagent (Invitrogen; Thermo Fisher Scientific, Inc.) in accordance with the manufacturer's instructions, respectively. Reverse Transcription kit (cat. no. 4366596; TaqMan ${ }^{\mathrm{TM}}$; Jiangsu Hongyao Biological Technology Co., Ltd.) was used to synthesize complementary DNA prior to qPCR. The primer sequences are listed in Table I. qPCR was performed using SYBR Premix Ex Taq (Perfect Real time; Takara Bio, Inc.) in accordance with the manufacturer's protocol, under the following thermocycling conditions: $60 \mathrm{sec}$ of initialization at $95^{\circ} \mathrm{C}$; 30 cycles of $15 \mathrm{sec}$ of denaturation at $95^{\circ} \mathrm{C}, 30 \mathrm{sec}$ of annealing at $60^{\circ} \mathrm{C}$ and $1 \mathrm{~min}$ of elongation $72^{\circ} \mathrm{C}$; followed by $10 \mathrm{~min}$ of elongation at $72^{\circ} \mathrm{C}$. Each measurement was repeated three times, while calculation and standardization of the relative expression were performed using the $2^{-\Delta \Delta \mathrm{Cq}}$ method (21). GAPDH was used as an internal control. 
Analysis of IGF $2 B P 2$ expression via western blotting (WB). WB was used to visualize IGF2BP2 protein expression after TE-1 and TE-10 transfection with siRNA-NC and siRNA-IGF2BP2. To lyse cells, samples were treated with $1 \mathrm{ml}$ RIPA buffer (Thermo Fisher Scientific, Inc.) and $100 \mu \mathrm{l}$ PMSF $(10 \mathrm{mM})$ at $4^{\circ} \mathrm{C}$ for $30 \mathrm{~min}$. Cell lysates were then collected and centrifuged at $10,000 \mathrm{x}$ g for $5 \mathrm{~min}$ at $4^{\circ} \mathrm{C}$ to obtain total protein. The concentration of protein was subsequently detected using a BCA kit (cat. no. P0011; Beyotime Institute of Biotechnology) and diluted to $10 \mu \mathrm{g} / \mathrm{l}$. Diluted protein $(4 \mu \mathrm{l})$ was added with $1 \mu 15 \mathrm{X}$ loading buffer, mixed and boiled for $4 \mathrm{~min}$ at $100^{\circ} \mathrm{C}$. Protein samples (50 ng) of each group, including TE-1 and TE-10 cells transfected with siRNA-NC and siRNA-IGF2BP2, were then separated using $8 \%$ SDS-PAGE. Subsequently, proteins were transferred to PVDF membranes. Ponceau $\mathrm{S}$ staining was applied to confirm protein transfer to PVDF membrane at room temperature, after which $10 \%$ BSA and $0.05 \%$ Tween-20 in TBS was used to block the membranes at room temperature for $1 \mathrm{~h}$. Subsequently, the membranes were incubated overnight at $4^{\circ} \mathrm{C}$ with the following rabbit-derived primary antibodies: Anti-IGF2BP2 (1:2,000; cat. no. ab124930; Abcam) and anti-GAPDH (1:2,500; cat. no. ab9485; Abcam). After washing the membrane with TBST three times every 5 min, the membranes were incubated with HRP-conjugated goat-derived rabbit IgG antibody (1:2,000; cat. no. ab6721; Abcam) for $1 \mathrm{~h}$ at room temperature. Finally, after washing the membrane with TBST three times, the membranes were visualized using an Ultra High Sensitivity ECL kit (cat. no. GK10008; Gibco) and imaged with ChemiScope 3600 mini (Clinx; magnification, x10) in a dark room. GAPDH was used as an internal control and densitometry was performed using Image J (Java 1.8.0.172).

Clonogenic assays. TE-1 and TE-10 cells were seeded at a density of 1,000 cells per well in the six-well-plate and transfected with siRNAs, then incubated for 10 days at $37^{\circ} \mathrm{C}$ with $5 \% \mathrm{CO}_{2}$. The cells were then fixed with $4 \%$ paraformaldehyde at room temperature for $30 \mathrm{~min}$ and stained with $1 \%$ crystal violet at room temperature for $20 \mathrm{~min}$. Next, colonies with a diameter $>20 \mu \mathrm{m}$ cells were recorded and imaged with a light microscope (Nikon Corporation; Ti-U; magnification, x200).

Cell cycle analysis using flow cytometry and DNA staining with PI. A total of $\sim 1 \times 10^{6}$ TE-1 and TE-10 cells were harvested, washed with PBS and suspended in $0.5 \mathrm{ml}$ PBS. Monodispersed cell suspensions were then obtained via a gentle vortex step with minimum clumping of cells. After overnight fixation of the cells in cold ethanol $(70 \%)$ at $4^{\circ} \mathrm{C}$, centrifugation of the cells suspended in ethanol was performed for $5 \mathrm{~min}$ at $300 \mathrm{x} \mathrm{g}$ and $4^{\circ} \mathrm{C}$ before careful discarding the supernatant. PBS was subsequently used to wash the samples twice before resuspension in RNase $(20 \mu \mathrm{g} / \mathrm{ml})$ and PI $(50 \mu \mathrm{g} / \mathrm{ml})$ in PBS for $30 \mathrm{~min}$ at room temperature, to ensure that only DNA and not RNA was stained. Subsequently, the analysis of stained cells was performed via flow cytometric analysis (BD LSRFortessa ${ }^{\mathrm{TM}}$; Beckman Coulter, Inc.) and analyzed by Flow Jo V10 (FlowJo LLC).

Wound healing assay to monitor cell migration. TE-1 and TE-10 cell lines transfected with siRNA in addition to blank control groups were seeded in six-well plates at a density of
$2 \times 10^{5}$ cells/well with DMEM supplemented with $10 \%$ FBS and $1 \%$ penicillin-streptomycin. A scratch was introduced when the cell confluence reached $\sim 80 \%$. After washing the cells twice with PBS, samples were incubated in DMEM supplemented with $1 \%$ PS only. Wound healing assay images were recorded automatically every $4 \mathrm{~h}$. An inverted fluorescence microscope (Nikon Corporation; Ti-U; magnification, x200) was used to monitor cell migration at $0,12,24$ and $48 \mathrm{~h}$ after introducing the scratch. Images were analyzed using Image $\mathbf{J}$ (Java 1.8.0.172; National Institutes of Health).

Cell proliferation assay using cell counting kit-8 (CCK-8). Cell proliferation was assayed after the inhibition of IGF2BP2 expression in TE-1 and TE-10 cells using a CCK-8 Cell Proliferation and Cytotoxicity Assay kit (cat. no. CA1210; Beijing Solarbio Science \& Technology Co., Ltd.). A total of $5 \times 10^{3}$ cells per $\mathrm{ml}$ were inoculated into a $96-$-well plate $(100 \mu \mathrm{l}$ per well) and divided into 'control' and 'IGF2BP2 siRNA' groups. At different time points, including 0, 24 and $48 \mathrm{~h}, \mathrm{CCK}-8(10 \mathrm{ml})$ was added to each well carefully to avoid the introduction of bubbles, after which plates were stored in an incubator for $2 \mathrm{~h}$ at $37^{\circ} \mathrm{C}$. Subsequently, a microplate reader was employed to measure the absorbance value at $450 \mathrm{~nm}$ in triplicate.

Cell apoptosis analysis with PI/Annexin V double staining. Harvested TE-1 and TE-10 cells were washed in PBS, after which $1 \times 10^{6}$ cells were resuspended and stained using Dead Cell Apoptosis Kit with Annexin V FITC and PI (V13242, Thermo Fisher) according to the standard protocol. Cell apoptosis was analyzed through flow cytometry (BD FACSCelesta ${ }^{\mathrm{TM}}$; BD Biosicences). The intensity of FITC/Annexin V fluorescence was analyzed using FlowJo V10 software (FlowJo LLC) and presented on the $\mathrm{x}$-axis, while PI (screened using phycoerythrin) was plotted on the $y$-axis. FITC/PI denoted living cells, $\mathrm{FITC}^{+} / \mathrm{PI}$ indicated early apoptotic cells, $\mathrm{FITC}^{+} / \mathrm{PI}^{+}$represented late apoptotic cells and FITC/PI ${ }^{+}$depicted necrotic cells.

Identification of senescent cells using the senescence-associated $\beta$-galactosidase (SA- $\beta$-gal) assay. Senescence in siRNA transfected and blank control cell cultures was detected using the Cellular Senescence Detection kit (Beiyi Bioequip Information Co., Ltd.) in accordance with the supplier's instructions. A total of $2 \times 10^{4}$ cells per ml were seeded in six-well plates at $2 \mathrm{ml}$ per well and cultured for 2 days at $37^{\circ} \mathrm{C}$. The cells were washed with PBS and fixed with $4 \%$ paraformaldehyde for $30 \mathrm{~min}$ at room temperature. The cells were subsequently washed with PBS twice, after which $1 \mathrm{ml}$ SA- $\beta$-gal staining solution was added prior to incubation at $37^{\circ} \mathrm{C}$ for $15 \mathrm{~min}$. After blue coloring was fully developed, cells were washed twice with PBS. A single drop of mounting medium was added before cover glasses were placed atop the six-well plate. SA- $\beta$-gal-blue positive cells were counted using an inverted fluorescence microscope (Nikon Corporation; Ti-U; magnification, x200).

Detection of DNA synthesis in proliferating cells using a 5-ethynyl-2'-deoxyuridine (EdU) assay. Analysis of proliferating TE-1 and TE-10 cells after treatment with siRNA-IGF2BP2 or siRNA-NC was carried out using the BeyoClick $^{\mathrm{TM}}$ EdU cell proliferation kit with Alexa Fluro 488 
Table I. Primer sequences of reverse transcription-quantitative PCR.

\begin{tabular}{lll}
\hline Gene & Forward primer sequence (5'-3') & Reverse primer sequence $\left(5^{\prime}-3^{\prime}\right)$ \\
\hline GAPDH & GTCTCCTCTGACTTCAACAGCG & ACCACCCTGTTGCTGTAGCCAA \\
IGF2BP2 & GGCTCCCTGATCTGGTTAAGGA & CCACTTCCATTCTGATGACCAGC
\end{tabular}

IGF2BP2, insulin-like growth factor 2 mRNA-binding protein 2.
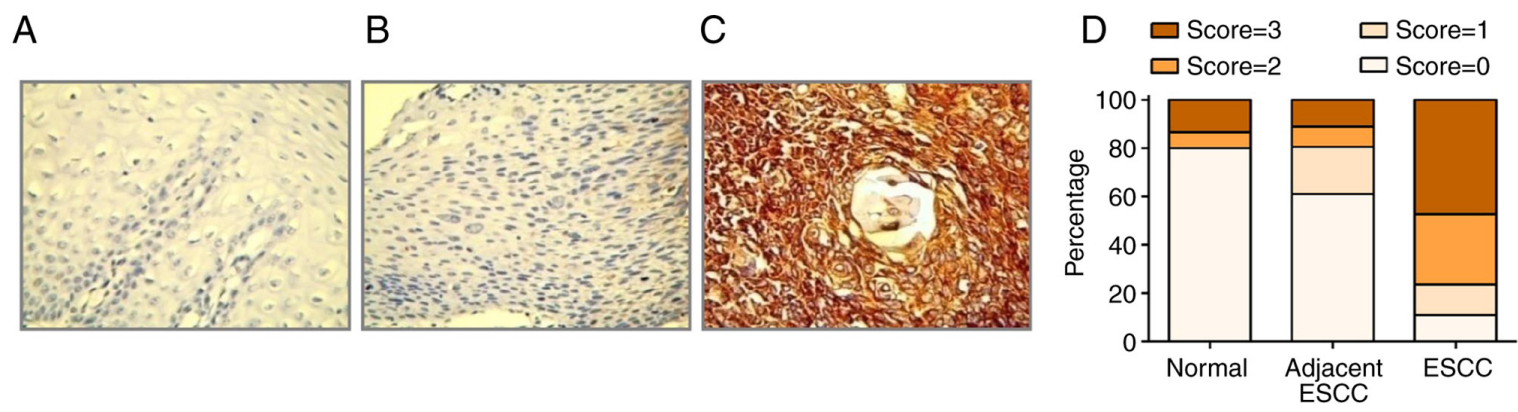

Figure 1. Analysis of IGF2BP2 expression using IHC. Images of (A) Normal esophageal, (B) adjacent ESCC and (C) ESCC tissue are presented (magnification, x400). (D) IHC staining comparing the intensity of IGF2BP2 staining in 36 ESCC tissues, 36 adjacent ESCC tissues and 15 normal esophageal tissues. IGF2BP2, insulin-like growth factor 2 mRNA-binding protein 2; IHC, immunohistochemistry; ESCC, esophageal-squamous cell carcinoma.

(Beyotime Institute of Biotechnology) based on the manufacturer's protocol. Subsequently, EdU (10 mM) was added to cells after transfection, after which samples were incubated at $37^{\circ} \mathrm{C}$ for $2 \mathrm{~h}$. Cells were then fixed for $30 \mathrm{~min}$ at room temperature with standard formaldehyde $(4 \%)$ and permeabilized with Triton X-100 $(0.5 \%)$ prior to staining at room temperature for $0.5 \mathrm{~h}$ with a Ultra High Sensitivity ECL kit. DAPI $(5 \mathrm{mg} / \mathrm{ml})$ was applied for $15 \mathrm{~min}$ to stain cell nuclei at room temperature before observation using a fluorescent microscope (Nikon Corporation; Ti-U; magnification, $\mathrm{x} 200$ ).

Statistical analysis. All data are presented as the mean $\pm \mathrm{SD}$, and at least three independent experiments were performed. The construction of graphs and the statistical analysis of data was performed using $\chi^{2}$ test and one-way ANOVA followed by Dunnett's post hoc test, with GraphPad Prism 6.0 (GraphPad Inc.) and SPSS 17.0 (SPSS, Inc.) software, respectively. $\mathrm{P}<0.05$ was considered to indicate a statistically significant difference.

\section{Results}

IGF2BP2 is upregulated in human ESCC tissue samples compared with adjacent ESCC tissue samples. IHC staining was performed to determine IGF2BP2 expression levels in 94 specimens of human ESCC tissues, which are listed in Table I. Due to the limitation of patient tumor size, 36 ESCC tissues were screened from the 94 specimens, with 15 adjacent healthy tissues obtained from the 36 specimens. IGF2BP2 was notably distributed in the nucleus and cytoplasm of squamous epithelial cells, as well as smooth muscle and stromal cells. The respective IHC images and scores of IGF2BP2 expression on normal, adjacent ESCC and ESCC tissues are presented in Fig. 1. A substantially higher IGF2BP2 expression was observed in ESCC and adjacent ESCC samples compared with normal healthy tissues. The results also revealed that $\sim 78 \%$ of ESCC samples exhibited a strongly positive IGF2BP2 expression, while $15 \%$ demonstrated a moderate expression and $7 \%$ exhibited a weak expression. Altogether, the increased expression of IGF2BP2 may serve as a marker of human ESCC.

Clinical relevance of IGF2BP2 expression in ESCC tissues. The association between IGF2BP2 and the clinicopathological characteristics of patients with ESCC was assessed. $\chi^{2}$ test analysis revealed a significant association between IGF2BP2 expression, tumor differentiation $(\mathrm{P}=0.038)$, TNM stages $(\mathrm{P}=0.018)$, lymph node metastasis $(\mathrm{P}<0.001)$ and lymphatic infiltration $(\mathrm{P}<0.001)$. Non-significant differences were observed in sex $(\mathrm{P}=0.379)$ and age $(\mathrm{P}=0.775$; Table II). In patients with ESCC, IGF2BP2 expression in III-IV grade tumors was markedly upregulated compared with grades I-II, as presented in Table II. Overall, IGF2BP2 expression was established to be associated with the progression of ESCC.

IGF2BP2 expression in ESCC cell lines. IGF2BP2 mRNA levels in TE-1 and TE-10 cell lines were quantified by performing RT-qPCR. As presented in Fig. 2A, the mRNA expression level of IGF2BP2 significantly increased in TE-1 cells compared with TE-10 cells. Subsequently, siRNAs targeting IGF2BP2 were transfected to knock down its expression in TE-1 and TE-10 cells (Fig. 2B and C), while siRNA-NC was used as negative control. The results of WB indicated that IGF2BP2 expression levels were significantly inhibited after siRNA transfection in both TE-1 and TE-10 cells.

IGF2BP2 knockdown inhibits the proliferation and migration of ESCC cells. To study the effect of IGF2BP2 in ESCC cell proliferation, a CCK-8 assay was performed to investigate the viability of siRNA-transfected TE-1 and TE-10 cells. As 
Table II. Association between insulin-like growth factor 2 mRNA-binding protein 2 protein expression and clinicopathological features of esophageal squamous cell carcinoma.

Insulin-like growth factor 2 mRNA-binding protein 2 protein expression

\begin{tabular}{|c|c|c|c|c|c|}
\hline Variable & $\begin{array}{l}\text { Number } \\
\text { of cases }\end{array}$ & $\begin{array}{c}\text { Median } \\
(\mathrm{P} 25, \mathrm{P} 75)\end{array}$ & $\begin{array}{c}\text { Low } \\
\text { (score; } 0 \text { or } 1), \mathrm{n}\end{array}$ & $\begin{array}{c}\text { High } \\
\text { (score; } 2 \text { or } 3), \mathrm{n}\end{array}$ & P-value \\
\hline Sex & & & & & 0.379 \\
\hline Male, $\mathrm{n}$ & 66 & $3(1,3)$ & 20 & 46 & \\
\hline Female, $\mathrm{n}$ & 28 & $3(2,3)$ & 6 & 22 & \\
\hline Age & & & & & 0.775 \\
\hline$<64$ & 52 & $3(1,3)$ & 15 & 37 & \\
\hline$\geq 64$ & 42 & $3(1,3)$ & 11 & 31 & \\
\hline $\begin{array}{l}\text { Degree of } \\
\text { tumor } \\
\text { differentiation }\end{array}$ & & & & & 0.038 \\
\hline High & 20 & $1.5(1,3)$ & 10 & 10 & \\
\hline Middle & 47 & $3(2,3)$ & 11 & 36 & \\
\hline Low & 27 & $3(2,3)$ & 5 & 22 & \\
\hline $\begin{array}{l}\text { Tumor, node and } \\
\text { metastasis staging }\end{array}$ & & & & & 0.018 \\
\hline I-II & 62 & $2(1,3)$ & 22 & 40 & \\
\hline III-IV & 32 & $3(2,3)$ & 4 & 28 & \\
\hline $\begin{array}{l}\text { Lymph node } \\
\text { metastasis }\end{array}$ & & & & & $<0.001$ \\
\hline Positive & 38 & $3(3,3)$ & 3 & 35 & \\
\hline Negative & 56 & $2(1,3)$ & 23 & 33 & \\
\hline $\begin{array}{l}\text { Lymphatic } \\
\text { infiltration }\end{array}$ & & & & & $<0.001$ \\
\hline Positive & 43 & $3(2,3)$ & 4 & 39 & \\
\hline Negative & 51 & $2(1,3)$ & 22 & 29 & \\
\hline
\end{tabular}

A

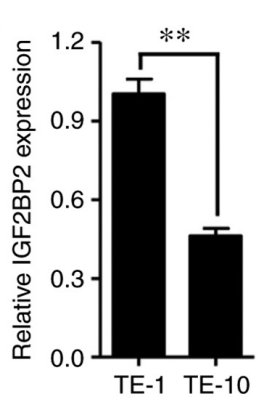

B
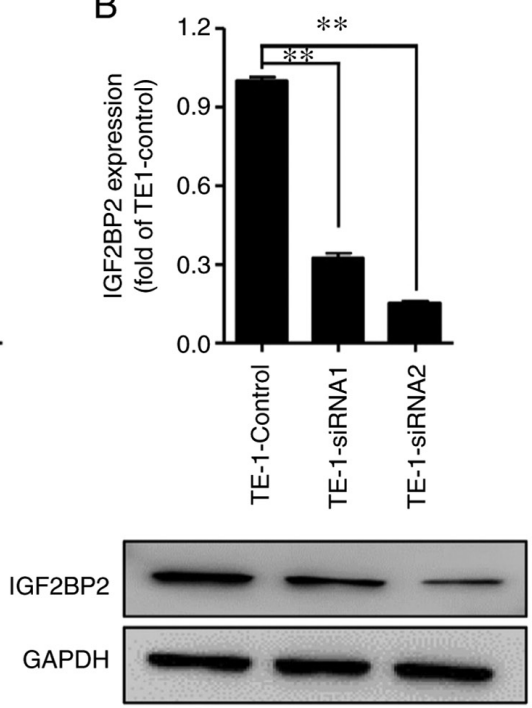

C

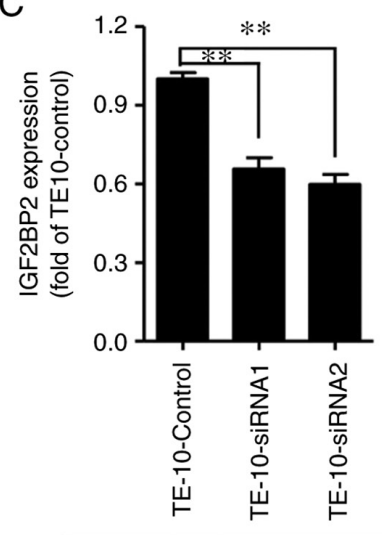

IGF2BP2

GAPDH

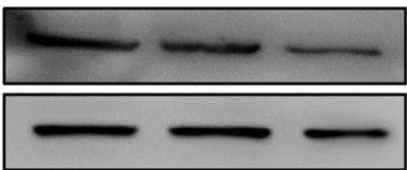

Figure 2. Analysis of IGF2BP2 expression using RT-qPCR and western blotting. (A) The relative mRNA expression of IGF2BP2 was detected via RT-qPCR in ESCC cell lines (TE-1 and TE-10). The transfection efficiency of each siRNA targeting IGF2BP2 was assessed in (B) TE-1 and (C) TE-10 cell lines by western blotting. One-way ANOVA followed by Dunnett's post hoc test were performed to analyze data. ${ }^{* *} \mathrm{P}<0.01$ vs. control group. IGF2BP2, insulin-like growth factor 2 mRNA-binding protein 2; RT-qPCR, reverse transcription-quantitative PCR; ESCC, esophageal-squamous cell carcinoma; siRNA, small interfering RNA. 

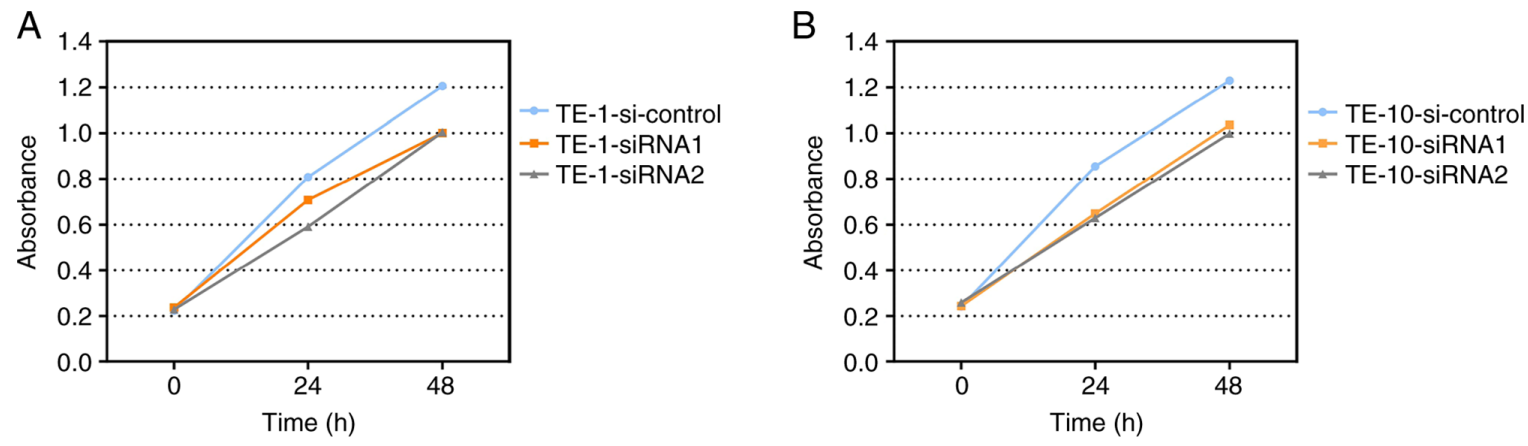

Figure 3. IGF2BP2 expression knockdown decreases esophageal-squamous cell carcinoma cell viability, as determined by using a Cell Counting Kit-8 assay. Quantitative analysis of optical density values was performed in (A) TE-1 and (B) TE-10 cell lines treated with siRNA-IGF2BP2 or siRNA-control. Cell viability was determined at 24 and 48 h. IGF2BP2, insulin-like growth factor 2 mRNA-binding protein 2; siRNA, small interfering RNA.
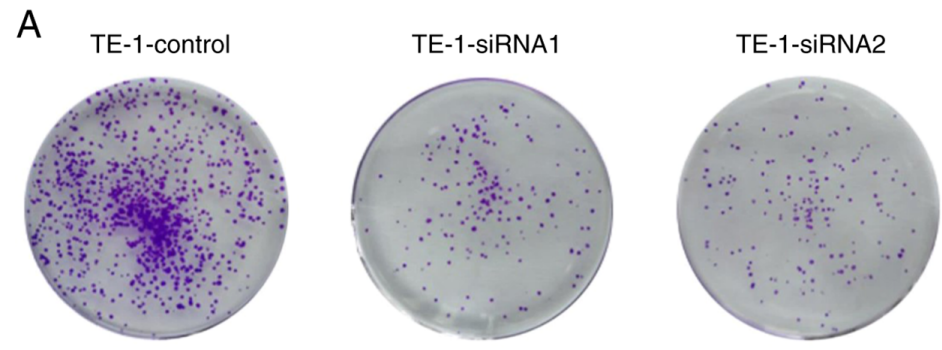

C
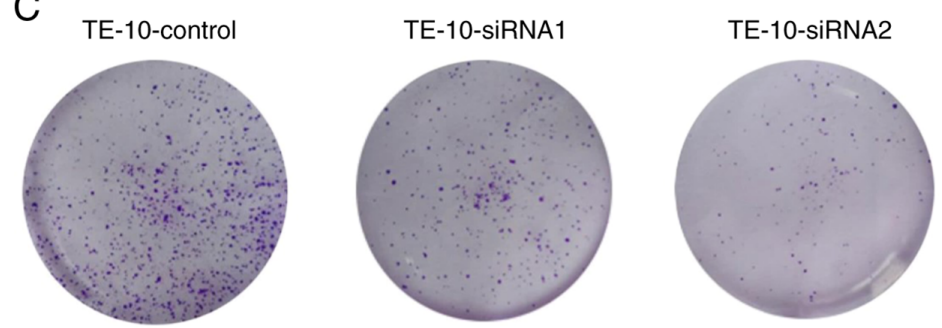
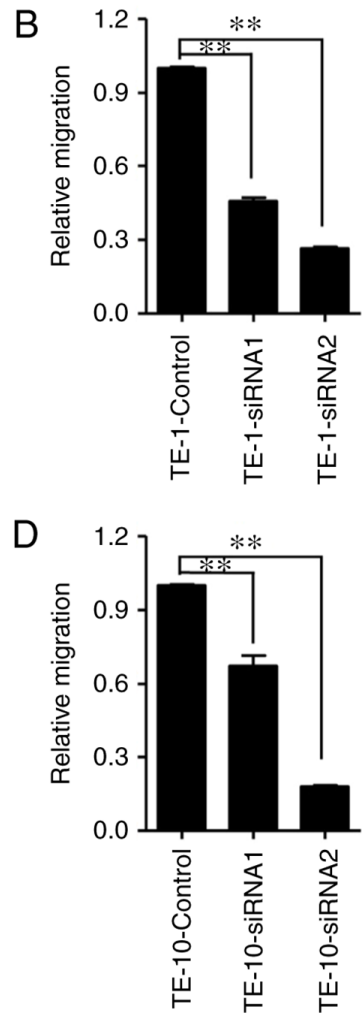

Figure 4. IGF2BP2 modulates esophageal-squamous cell carcinoma colony formation. Quantitative analysis of (A) TE-1 and (B) TE-10 colony numbers after transfection with siRNAs targeting IGF2BP2 or siRNA-control. IGF2BP2 knockdown in (C) TE-1 and (D) TE-10 cells significantly decreased colony formation. One-way ANOVA followed by Dunnett's post hoc test was performed to analyze data. ${ }^{* *} \mathrm{P}<0.01$ vs. control group. IGF2BP2, insulin-like growth factor 2 mRNA-binding protein 2; ESCC, esophageal-squamous cell carcinoma; siRNA, small interfering RNA.

indicated in Fig. 3, the number of living cells was markedly decreased in the two siRNA-IGF2BP2 groups compared with the siRNA-NC group. In addition, the results of the SA- $\beta$-gal positive clone assay revealed that IGF2BP2 was significantly less capable of generating clones after siRNA1 and siRNA2 transfection in TE-1 and TE-10 cells compared with the control group (Fig. 4). Furthermore, the effect of the siRNA2 treated group was significantly decreased compared with the siRNA1 group. The results of the EdU assay demonstrated similar results to the clonal assay. The colorimetric detection of SA- $\beta$-gal and EdU assays revealed that ESCC cellular senescence and DNA synthesis replication, involved in the process of proliferation, were positively associated with IGF2BP2 expression (Fig. 5).
Since IGF2BP2 was highly expressed in lymphatic infiltration metastasis of ESCC tissues (22), the role of IGF2BP2 in ESCC cell migratory activity was studied in vitro using a wound healing assay. The results revealed an increased wound width after scratch introduction in the two siRNA-IGF2BP2 groups compared with the siRNA-NC group. These results implied that ESCC cell migration was suppressed by IGF2BP2 knockdown (Fig. 6). The present findings indicated that IGF2BP2 could play a crucial role in the inhibition of ESCC cell proliferation and migration.

IGF2BP2 knockdown induces cell cycle arrest and ESCC cell apoptosis. Flow cytometry assays were performed to determine whether IGF2BP2 could regulate cell cycle 
A
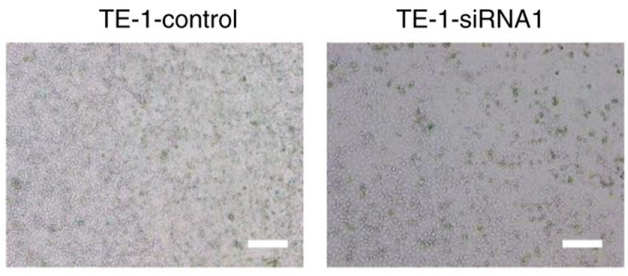

B
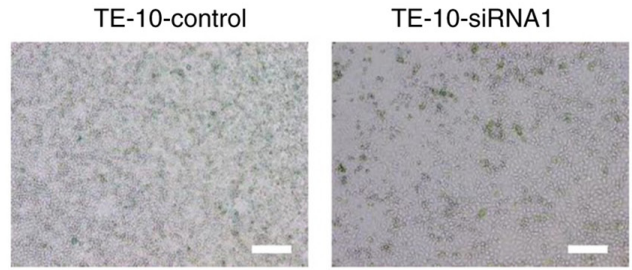

C
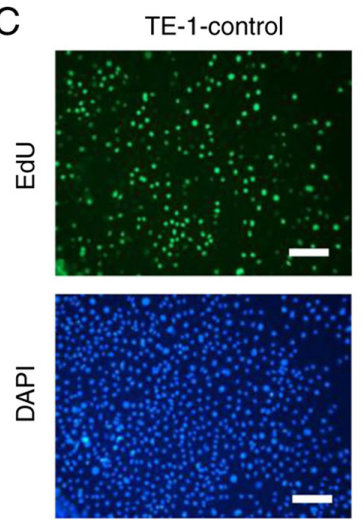

$\mathrm{D}$
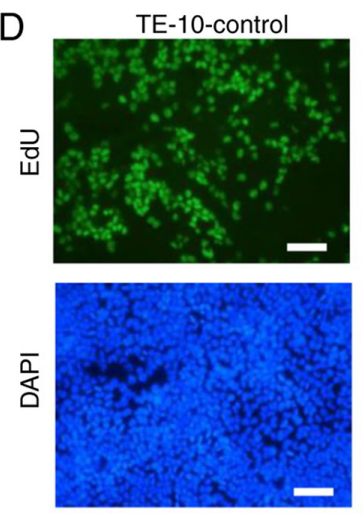

TE-1-SiRNA1
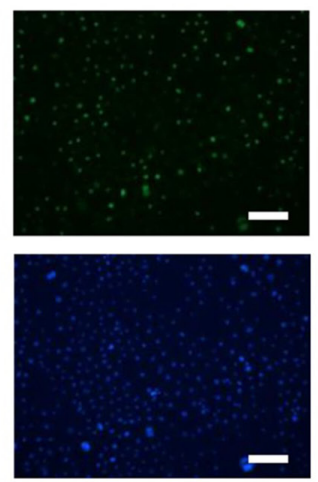

TE-10-siRNA1
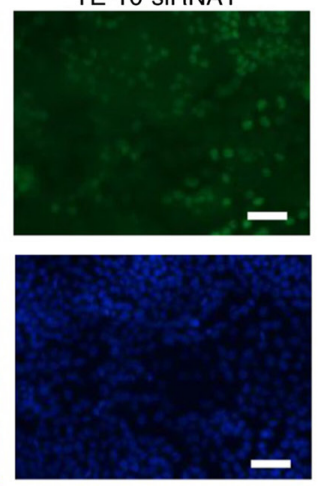

TE-1-siRNA2

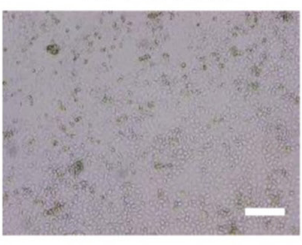

TE-10-siRNA2

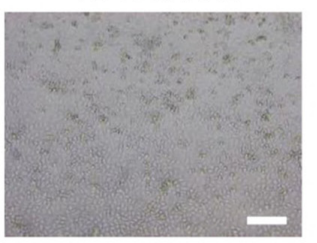

TE-1-SiRNA2
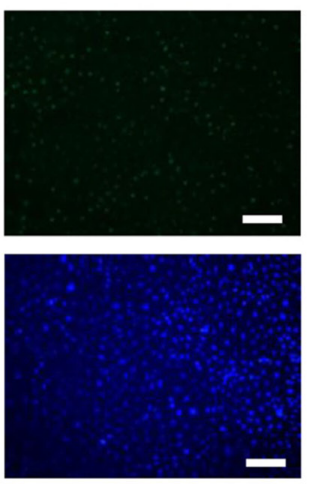

TE-10-siRNA2
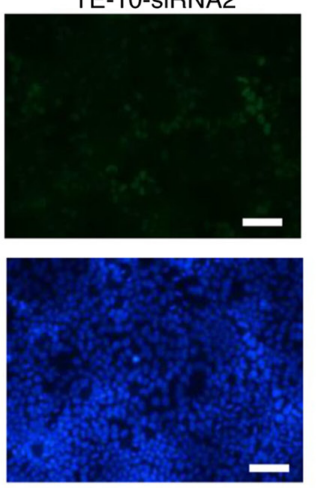
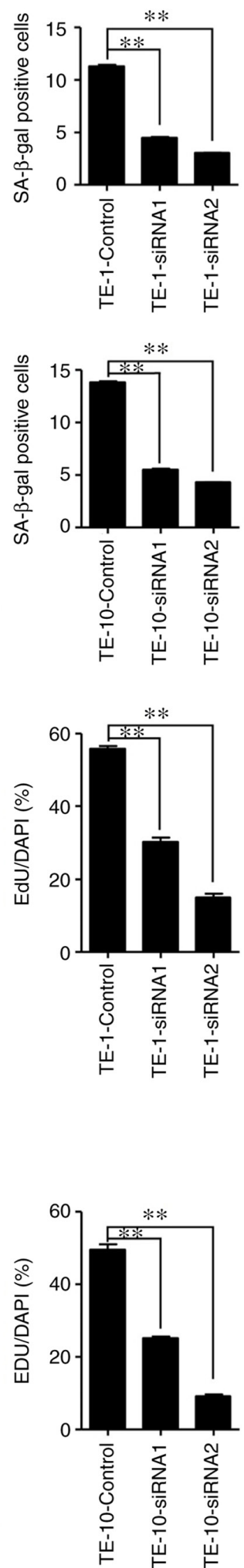

Figure 5. Senescence and proliferation assays. SA- $\beta$-gal-positive cells were counted inTE-1 (A) and TE-10 (B) cell lines. Senescence was decreased inTE-1 (C) and TE-10 (D) cells treated with siRNA1 and siRNA2 targeting IGF2BP2 that were labeled with EdU or DAPI, when compared with the control group. One-way ANOVA followed by Dunnett's post hoc test was performed to statistically analyze data. ${ }^{* *} \mathrm{P}<0.01$ vs. control group. SA- $\beta$-gal, senescence-associated $\beta$-galactosidase; EdU, 5-ethynyl-2'-deoxyuridine; IGF2BP2, insulin-like growth factor 2 mRNA-binding protein 2; siRNA, small interfering RNA.

progression in TE-1 and TE-10 cells after transfection with two siRNA-IGF2BP2s or siRNA-NC. The percentage of cells at distinct phases is indicated in Fig. 7, with results demonstrating that IGF2BP2 knockdown induced significant cell cycle arrest at the G1 phase compared with siRNA-NC-treated cells. The present results suggested that IGF2BP2 participates in the regulation of the G1/S transition during ESCC cell cycle progression. Furthermore, the role of 
A

TE-1-control

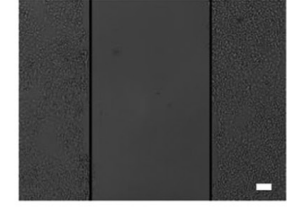

B

TE-10-control

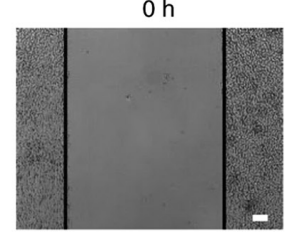

TE-10-siRNA

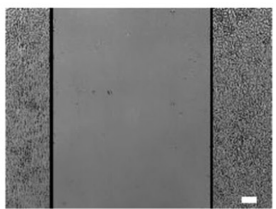

TE-10-siRNA2

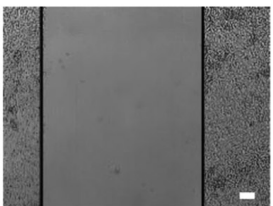

C

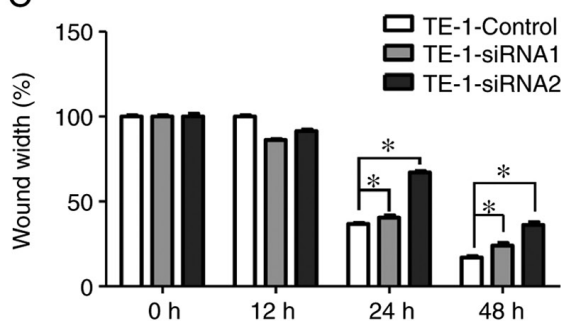

$12 \mathrm{~h}$
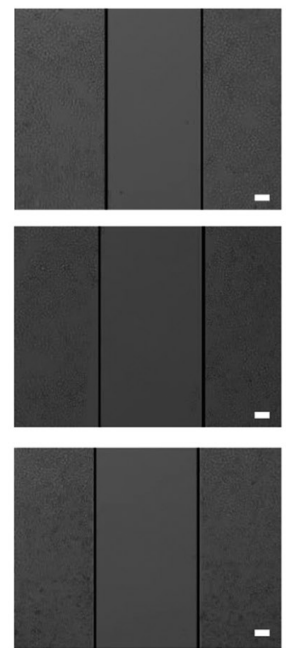

$12 \mathrm{~h}$
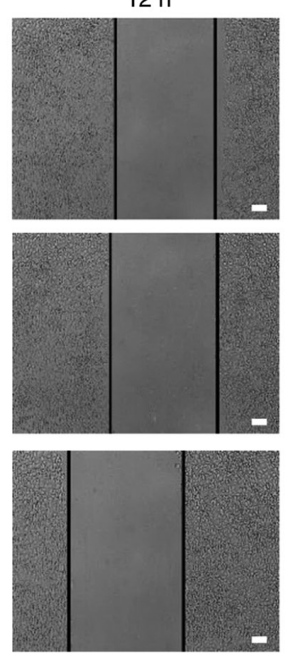

$24 \mathrm{~h}$
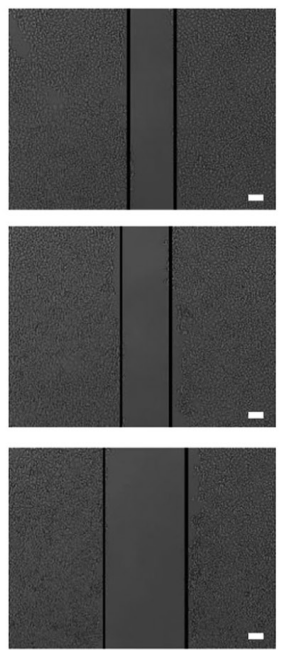

$24 \mathrm{~h}$
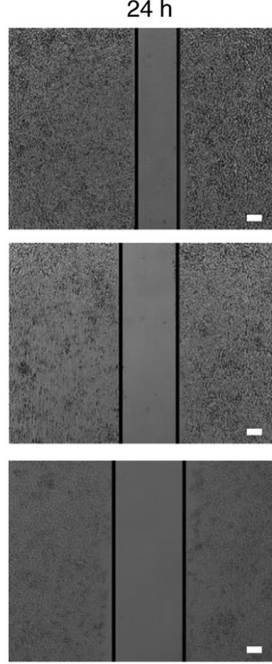

D

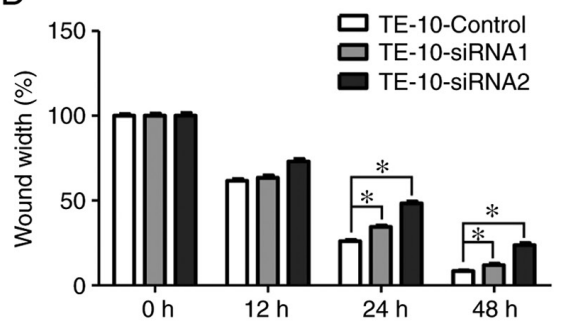

Figure 6. Esophageal-squamous cell carcinoma cell migration following treatment with siRNA-IGF2BP2 or siRNA-control, as analyzed using wound healing assays. Respective images of wound healing in (A) TE-1 and (B) TE-10 cells treated with siRNA-IGF2BP2 or siRNA-control are presented. Light microscope images were obtained at 12, 24 and $48 \mathrm{~h}$ after the scratch was introduced. Corresponding wound width data of (C) TE-1 and (D) TE-10 cells is presented. Scale bar, $100 \mu \mathrm{m}$. One-way ANOVA followed by Dunnett's post hoc test was performed to statistically analyze the data. ${ }^{*}<0.05$ vs. control group. IGF2BP2, insulin-like growth factor 2 mRNA-binding protein 2; siRNA, small interfering RNA.

IGF2BP2 in apoptosis was investigated by performing flow cytometry with PI/Annexin V double staining. The apoptosis rate of IGF2BP2-siRNA-treated cells was significantly increased compared with siRNA-NC-treated cells (Fig. 8). Early apoptotic cell percentages were similar between siRNA-IGF2BP2-treated and siRNA-NC-treated cells (Q3), whereas late apoptotic cells were markedly increased in siRNA-IGF2BP2-treated cell lines after $48 \mathrm{~h}$ of transfection (Q4). Altogether, the present findings indicated that the inhibition of IGF2BP2 significantly reduced tumor cell proliferation and migration, and increased the senescence of tumor cells, suggesting that IGF2BP2 may be a key regulatory oncogene for tumorigenesis in ESCC cells.

\section{Discussion}

ESCC is a commonly diagnosed cancer of the digestive system, and concerns have been growing worldwide owing to its high incidence and mortality rate, in developing nations such as China or India (23). Despite the approval of several treatment options, the prognosis of patients in advanced stages, along with their overall survival rate remains low (24). 

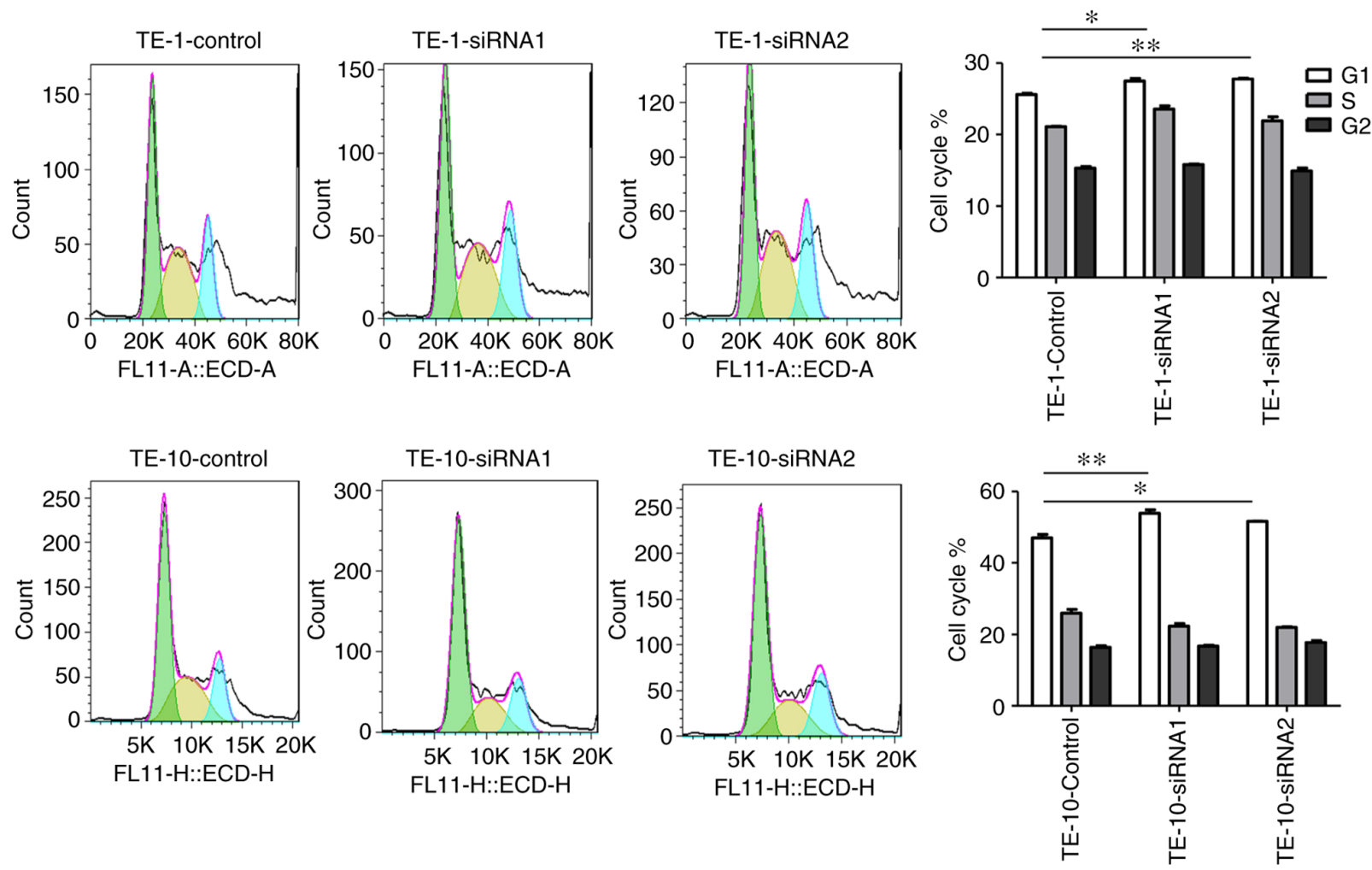

Figure 7. IGF2BP2 is required for cell cycle progression. Cell cycle distribution of esophageal-squamous cell carcinoma cells transfected with siRNA-control or siRNA-IGF2BP2 was assessed by performing flow cytometry in (top) TE-1 and (bottom) TE-10 cells. Transfection with siRNA-IGF2BP2 significantly reduced cell growth compared with the siRNA-control. One-way ANOVA followed by Dunnett's post hoc test was performed to statistically analyze data. ${ }^{*} \mathrm{P}<0.05$ and ${ }^{*} \mathrm{P}<0.01$ vs. control group. IGF2BP2, insulin-like growth factor 2 mRNA-binding protein 2; siRNA, small interfering RNA.

A

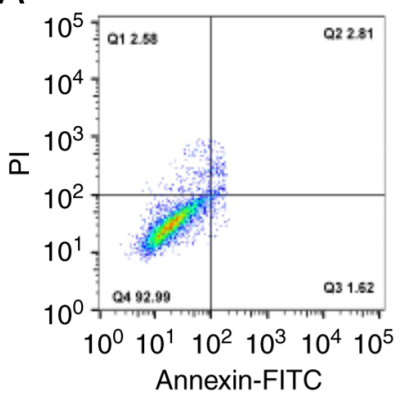

B

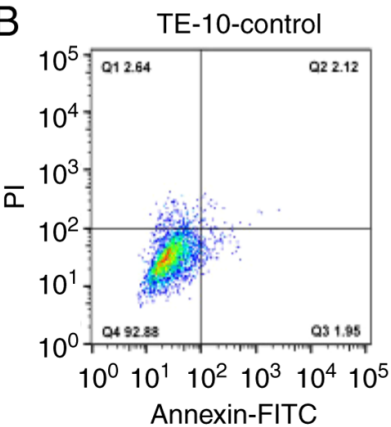

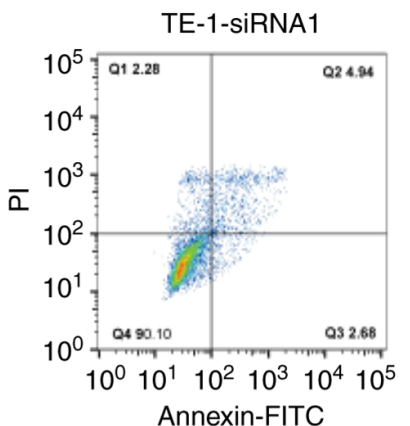

TE-10-siRNA1

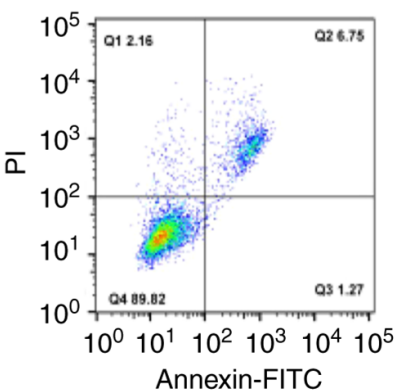

TE-1-siRnA2

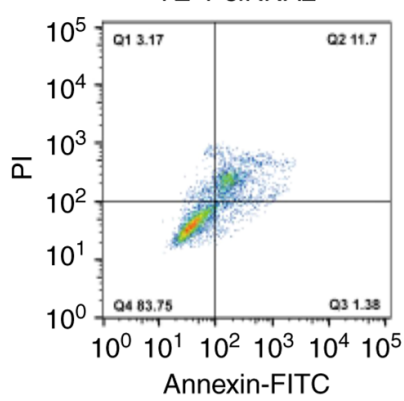

TE-10-siRNA2

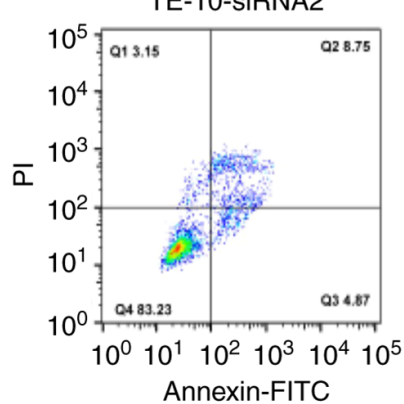

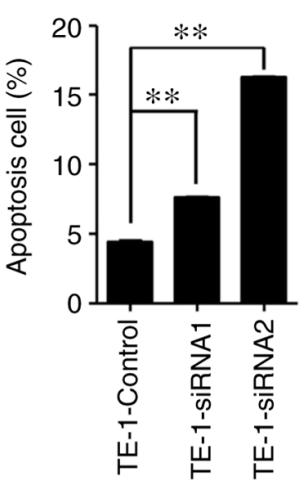

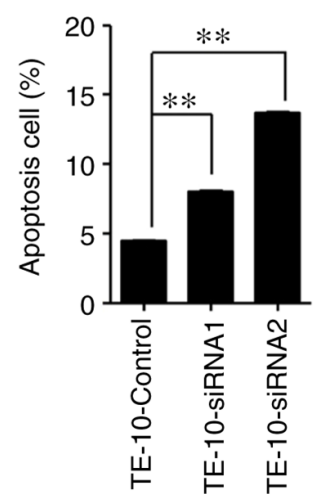

Figure 8. Detection of apoptosis by Annexin V/PI staining in esophageal-squamous cell carcinoma cells transfected with siRNA-control or siRNA-IGF2BP2. (A) Flow cytometry plots were produced and (B) the percentage of apoptotic cells was determined in the TE-1 cell line. Flow cytometry plots were produced and the percentage of apoptotic cells was assessed in the TE-10 cell line. IGF2BP2 knockdown induced the apoptosis of TE-1 and TE-10 cells. One-way ANOVA followed by Dunnett's post hoc test was performed to statistically analyze data. ${ }^{* *} \mathrm{P}<0.01$ vs. control group. IGF2BP2, insulin-like growth factor 2 mRNA-binding protein 2; siRNA, small interfering RNA. 
The efficacy of chemotherapeutic agents for the treatment of ESCC, including docetaxel or paclitaxel, which have limited treatment potential and produce adverse effects in clinical settings (5). Therefore, it is important to find new therapeutic targets for ESCC therapy.

As an RNA-binding protein, IGF2BP2 has been revealed to post-transcriptionally drive the progression of cancer cells through its ability to regulate the trafficking, localization, stabilization and translation of mRNAs involved in important aspects of cellular functions (25). Various studies have reported its contribution in several physiological processes, such as embryo development, neuron metabolism, neuron differentiation and IFG2BP2 aberrant regulation, which causes insulin resistance, obesity, diabetes and carcinogenesis (26-28). IGF2BP2 is highly expressed in several types of cancer, including brain cancer (29), liver carcinoma (30), ovarian cancer (31), endometrial adenocarcinoma (32) and breast cancer (33). A previous study documented its tumorigenic role in promoting tumor growth, cell proliferation, migration and invasion (34). However, the function and expression profile of IFG2BP2 during ESCC development has not yet been elucidated. The present study reported that IGF2BP2 was upregulated in ESCC and its adjacent cancerous tissues, compared with normal adjacent tissues. IGF2BP2 expression was associated with increased clinical tumor stages, lymphatic infiltration and LNM. The present study also revealed that IGF2BP2 played regulatory roles in ESCC cell survival, proliferation and migration.

Autoantibodies against tumor-associated antigen (IGF2BP2/p62) have been revealed to increase as ESCC progresses (35). A previous study determined that IGF2BP2 expression was elevated in patients with EAC and precancerous Barret's esophagus lesion, with higher expression levels being associated with metastasis and the poor survival of patients (15). In the present study, IGF2BP2 expression was analyzed using RT-qPCR and IHC in ESCC, adjacent ESCC and normal tissues obtained from the same patient. Consistent with previous studies (36), the present findings indicated that IGF2BP2 expression was highly increased in a large proportion of patients with ESCC and substantially associated with the degree of tumor differentiation, TNM staging, LNM and lymphatic infiltration. Therefore, IGF2BP2 could act as an unfavorable biomarker for the development and prognosis of ESCC. Further studies are required to understand the association between IGF2BP2 expression and the survival rates of patients with ESCC.

A previous study demonstrated that miR-141 silencing induced the upregulation of IGF2BP2, which promoted pancreatic cancer cell proliferation and survival through the PI3K/AKT signaling pathway (37). In addition, newly discovered Cys-His protein 2 and muscle RING-finger 3 mRNAs have been determined to be post-transcriptionally regulated and involved in the regulatory mechanism of cytoskeleton remodeling and membrane integrity maintenance via IGF2BP2, and IFG2BP2 inhibition results in the reduction of cell motility and invasive capacity in rhabdomyosarcoma (38). Moreover, the dysregulation of IGF2BP2 and METTL3 was indicated to trigger colorectal cancer progression and metastasis (39). Changes in biological phenotypes in the progression of ESCC were then examined using ESCC cell lines (TE-1 and TE-10) transfected with IGF2BP2-siRNA in vitro, compared with siRNA-NC-treated cells. The present in vitro results were consistent with the clinical findings of IGF2BP2 in human ESCC tissues, indicating that the downregulation of IGF2BP2 negatively affected ESCC cell proliferation and migration by inducing cell cycle arrest and apoptosis. Therefore, IGF2BP2 may serve as a tumor promoter in ESCC.

The present work aimed to determine the expression profile of IGF2BP2 in ESCC and its association with the clinicopathological features of patients with ESCC. RT-qPCR analysis revealed that IGF2BP2 expression levels were elevated in ESCC tissues, while loss of function demonstrated that IGF2BP2 downregulation promoted ESCC cell apoptosis and suppressed cell proliferation and migration. The results of the present study may provide a valuable insight into the expression of IGF2BP2 in ESCC cell progression and may help to develop novel therapeutic approaches for ESCC diagnosis and therapy.

\section{Acknowledgements}

Not applicable.

\section{Funding}

The present work was supported by the Development Plant Projects of the Science and Technology at Suzhou (grant no. SYS2019008) and Changshu (grant no. CS201915).

\section{Availability of data and materials}

The datasets used and/or analyzed during the current study are available from the corresponding author on reasonable request.

\section{Authors' contributions}

FL conceived the manuscript. FL, WC and TJ conceptualized and designed the experiments. BW, ZL, GH and JQ performed the experiments. JQ, WW, MY and XH analyzed the data. FL, WC, TJ and BW contributed reagents, materials and analysis tools. FL, TJ, CC and BW drafted the manuscript. CC collected and verified patient raw data. WC and TJ confirm the authenticity of all the raw data. All authors have read and approved the final manuscript.

\section{Ethics approval and consent to participate}

Review and approval for the current study was obtained by the Ethical committee of Changshu Second People's Hospital at Jiangsu Province. Patients provided their written informed consent to participate in the present study.

\section{Patient consent for publication}

Not applicable.

\section{Competing interests}

The authors declare that they have no competing interests. 


\section{References}

1. Quaas A, Rehkaemper J, Rueschoff J, Pamuk A, Zander T, Hillmer A, Siemanowski J, Wittig J, Buettner R, Plum P, et al: Occurrence of high microsatellite-instability/mismatch repair deficiency in nearly 2,000 human adenocarcinomas of the gastrointestinal tract, pancreas, and bile ducts: A study from a large german comprehensive cancer center. Front Oncol 11: 569475, 2021.

2. Zhu J, Ma S, Xie S, Liu Z, Li Z and Wei W: Biological correlates before esophageal cancer screening and after diagnosis. Sci Rep 11: 17015, 2021

3. Sung H, Ferlay J, Siegel RL, Laversanne M, Soerjomataram I, Jemal A and Bray F: Global cancer statistics 2020: GLOBOCAN estimates of incidence and mortality worldwide for 36 cancers in 185 countries. CA Cancer J Clin 71: 209-249, 2021.

4. Napier KJ, Scheerer M and Misra S: Esophageal cancer: A review of epidemiology, pathogenesis, staging workup and treatment modalities. World J Gastrointest Oncol 6: 112-120, 2014.

5. Nakajima $M$ and Kato H: Treatment options for esophageal squamous cell carcinoma. Expert Opin Pharmacother 14: 1345-1354, 2013.

6. Tustumi F, Kimura MS, Takeda FR, Uema RH, Salum RAA Ribeiro-Junior U and Cecconello I: Prognostic factors and survival analysis in esophageal carcinoma. Arq Bras Cir Dig 29: 138-141, 2016 (In English, Portuguese).

7. Dai N, Ji F, Wright J, Minichiello L, Sadreyev R and Avruch J: IGF2 mRNA binding protein-2 is a tumor promoter that drives cancer proliferation through its client mRNAs IGF2 and HMGA1. Elife 6: e27155, 2017.

8. Ye S, Song W, Xu X, Zhao X and Yang L: IGF2BP2 promotes colorectal cancer cell proliferation and survival through interfering with RAF-1 degradation by miR-195. FEBS Lett 590: 1641-1650, 2016.

9. Pu J, Wang J, Qin Z, Wang A, Zhang Y, Wu X, Wu Y, Li W, Xu Z, $\mathrm{Lu} \mathrm{Y}$, et al: IGF2BP2 promotes liver cancer growth through an m6A-FEN1-dependent mechanism. Front Oncol 10: 578816 2020.

10. Dahlem C, Barghash A, Puchas P, Haybaeck J and Kessler SM: The insulin-like growth factor 2 mRNA binding protein IMP2/IGF2BP2 is overexpressed and correlates with poor survival in pancreatic cancer. Int J Mol Sci 20: 3204, 2019.

11. Janiszewska M, Suvà ML, Riggi N, Houtkooper RH, Auwerx J, Clément-Schatlo V, Radovanovic I, Rheinbay E, Provero P and Stamenkovic I: Imp2 controls oxidative phosphorylation and is crucial for preserving glioblastoma cancer stem cells. Genes Dev 26: 1926-1944, 2012

12. Simon Y, Kessler SM, Bohle RM, Haybaeck J and Kiemer AK: The insulin-like growth factor 2 (IGF2) mRNA-binding protein p62/IGF2BP2-2 as a promoter of NAFLD and HCC? Gut 63 861-863, 2014

13. He X, Li W, Liang X, Zhu X, Zhang L, Huang Y, Yu T, Li S and Chen Z: IGF2BP2 overexpression indicates poor survival in patients with acute myelocytic leukemia. Cell Physiol Biochem 51: 1945-1956, 2018.

14. Cleynen I, Brants JR, Peeters K, Deckers R, Debiec-Rychter M, Sciot R, Van de Ven WJ and Petit MM: HMGA2 regulates transcription of the Imp2 gene via an intronic regulatory element in cooperation with nuclear factor-kappaB. Mol Cancer Res 5 : 363-372, 2007.

15. Barghash A, Golob-Schwarzl N, Helms V, Haybaeck J and Kessler SM: Elevated expression of the IGF2 mRNA binding protein 2 (IGF2BP2/IMP2) is linked to short survival and metastasis in esophageal adenocarcinoma. Oncotarget 7: 49743-49750, 2016.

16. Li T, Hu PS, Lin JF, Ju HQ and Xu RH: IDDF2019-ABS-0290 IGF2BP2 facilitates tumor progression via an m6A-dependent mechanism in colorectal carcinoma. Gut 68 (Suppl 1): A1-A166, 2016.

17. Albores-Saavedra J, Adsay NV and Crawford JM: 'Tumours of the gallbladder and extrahepatic bile ducts', in WHO Classification of Tumours of the Digestive System. Bosman FT, Carneiro F, Hruban RH and Theise ND (eds). Lyon, France, IARC Press, pp263-276, 2010.

18. Sobin LH and Compton CC: TNM seventh edition: What's new, what's changed: Communication from the international union against cancer and the American joint committee on cancer. Cancer 116: 5336-5339, 2010
19. Puschhof J, Post Y, Beumer J, Kerkkamp HM, Bittenbinder M, Vonk FJ, Casewell NR, Richardson MK and Clevers H: Derivation of snake venom gland organoids for in vitro venom production. Nat Protoc 16: 1494-1510, 2021

20. Detre S, Saclani Jotti G and Dowsett M: A 'quickscore' method for immunohistochemical semiquantitation: Validation for oestrogen receptor in breast carcinomas. J Clin Pathol 48: 876-878, 1995

21. Livak KJ and Schmittgen TD: Analysis of relative gene expression data using real-time quantitative PCR and the 2(T)(-Delta Delta C) method. Methods 25: 402-408, 2001.

22. Yang H, Xu L, Qian H, Niu X, Zhao D, Zhao Z, Wu J, Liu L and Wang Y: Correlation between insulin-like growth factor binding protein 3 and metastasis-associated gene 1 protein in esophageal squamous cell carcinoma. Mol Med Rep 13: 4143-4150, 2016.

23. Alsop BR and Sharma P: Esophageal cancer. Gastroenterol Clin North Am 45: 399-412, 2016.

24. Short MW, Burgers KG and Fry VT: Esophageal cancer. Am Fam Physician 95: 22-28, 2017.

25. Bell JL, Wächter K, Mühleck B, Pazaitis N, Köhn M, Lederer M and Hüttelmaier S: Insulin-like growth factor 2 mRNA-binding proteins (IGF2BPs): Post-transcriptional drivers of cancer progression? Cell Mol Life Sci 70: 2657-2675, 2013.

26. Gu T, Horová E, Möllsten A, Seman NA, Falhammar H, Prázný M, Brismar K and Gu HF: IGF2BP2 and IGF2 genetic effects in diabetes and diabetic nephropathy. J Diabetes Complications 26: 393-398, 2012.

27. Dai N, Zhao L, Wrighting D, Krämer D, Majithia A, Wang Y, Cracan V, Borges-Rivera D, Mootha VK, Nahrendorf M, et al: IGF2BP2/IMP2-deficient mice resist obesity through enhanced translation of Ucp1 mRNA and other mRNAs encoding mitochondrial proteins. Cell Metab 21: 609-621, 2015.

28. Hou P, Meng S, Li M, Lin T, Chu S, Li Z, Zheng J, Gu Y and Bai J: LINC00460/DHX9/IGF2BP2 complex promotes colorectal cancer proliferation and metastasis by mediating HMGA1 mRNA stability depending on m6A modification. J Exp Clin Cancer Res 40: 52, 2021.

29. Mu Q, Wang L, Yu F, Gao H, Lei T, Li P, Liu P, Zheng X, Hu X, Chen $\mathrm{Y}$, et al: Imp2 regulates GBM progression by activating IGF2/PI3K/Akt pathway. Cancer Biol Ther 16: 623-633, 2015.

30. Lu M, Nakamura RM, Dent ED, Zhang JY, Nielsen FC, Christiansen J, Chan EK and Tan EM: Aberrant expression of fetal RNA-binding protein p62 in liver cancer and liver cirrhosis. Am J Pathol 159: 945-953, 2001.

31. Liu X, Ye H, Li L, Li W, Zhang Y and Zhang JY: Humoral autoimmune responses to insulin-like growth factor II mRNA-binding proteins IMP1 and p62/IMP2 in ovarian cancer. J Immunol Res 2014: 326593, 2014

32. Zhang L, Liu Y, Hao S, Woda BA and Lu D: IMP2 expression distinguishes endometrioid from serous endometrial adenocarcinomas. Am J Surg Pathol 35: 868-872, 2011.

33. McMullen ER, Gonzalez ME, Skala SL, Tran M, Thomas D Djomehri SI, Burman B, Kidwell KM and Kleer CG: CCN6 regulates IGF2BP2 and HMGA2 signaling in metaplastic carcinomas of the breast. Breast Cancer Res Treat 172: 577-586, 2018

34. Cao J, Mu Q and Huang $\mathrm{H}$ : The roles of insulin-like growth factor 2 mRNA-binding protein 2 in cancer and cancer stem cells. Stem Cells Int 2018: 4217259, 2018.

35. Wu X, Fan Y, Liu Y, Shen B, Lu H and Ma H: Long non-coding RNA CCAT2 promotes the development of esophageal squamous cell carcinoma by inhibiting miR-200b to upregulate the IGF2BP2/TK1 axis. Front Oncol 11: 680642, 2021.

36. Zhou SL, Yue WB, Fan ZM, Du F, Liu BC, Li B, Han XN, Ku JW, Zhao XK, Zhang P, et al: Autoantibody detection to tumor-associated antigens of P53, IMP1, P16, cyclin B1, P62, $\mathrm{C}$-myc, Survivn, and Koc for the screening of high-risk subjects and early detection of esophageal squamous cell carcinoma. Dis Esophagus 27: 790-797, 2014

37. Xu X, Yu Y, Zong K, Lv P and Gu Y: Up-regulation of IGF2BP2 by multiple mechanisms in pancreatic cancer promotes cancer proliferation by activating the PI3K/Akt signaling pathway. J Exp Clin Cancer Res 38: 497, 2019.

38. Boudoukha S, Cuvellier S and Polesskaya A: Role of the RNA-binding protein IMP-2 in muscle cell motility. Mol Cell Biol 30: 5710-5725, 2010

39. Li T, Hu PS, Zuo Z, Lin JF, Li X, Wu QN, Chen ZH, Zeng ZL, Wang F, Zheng J, et al: METTL3 facilitates tumor progression via an m6A-IGF2BP2-dependent mechanism in colorectal carcinoma. Mol Cancer 18: 112, 2019. 